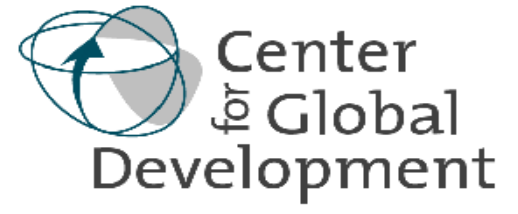

Working Paper Number 163

March 2009

Rice Crisis Forensics: How Asian Governments Carelessly Set the World Rice Market on Fire

By Tom Slayton

Abstract
The world rice market was aflame last spring and for several months it looked as if
the trading edifice that had exhibited such resilience over the last two decades was
going to burn to the ground. World prices trebled within less than four months and
reached a 30-year inflation-adjusted high. Many market observers thought the
previous record set in 1974 would soon be toast. The fire was man-made, not the
result of natural developments. While the governments in India, Vietnam, and the
Philippines did not to set the world market on fire, that was the unintended result of
their actions which threatened both innocent bystanders (low-income rice importers
as far away as Africa and Latin America) and, ultimately, poor rice consumers at
home. This paper describes what sparked the fire and the accelerants that made a
bad situation nearly catastrophic. Fortuitously, when the flames were raging at peak
intensity, rain clouds appeared, the winds [market psychology] shifted, and
conditions on the ground improved, allowing the fire to die down. It remains to be
seen, however, if the trading edifice has been seriously undermined by the actions
of decision makers in several key Asian rice exporting and importing countries. In
describing the cascading negative effects of these seemingly rational domestic
policies, this paper aims to help policy makers in the rice exporting and importing
nations to avoid a repeat of the disastrous price spike of 2008.

The Center for Global Development is an independent, nonprofit policy research organization that is dedicated to reducing global poverty and inequality and to making globalization work for the poor. This paper was made possible in part by funding from the William and Flora Hewlett Foundation and the John D. and Catherine T. MacArthur Foundation.

Use and dissemination of this Working Paper is encouraged; however, reproduced copies may not be used for commercial purposes. Further usage is permitted under the terms of the Creative Commons License. The views expressed in this paper are those of the author and should not be attributed to the board of directors or funders of the Center for Global Development.

www.cgdev.org 
Tom Slayton. 2009. "Rice Crisis Forensics: How Asian Governments Carelessly Set the World Rice Market on Fire." CGD Working Paper 163. Washington, D.C.: Center for Global Development. http://www.cgdev.org/content/publications/detail/1421260/ 


\title{
Rice Crisis Forensics: How Asian Governments Carelessly Set the World Rice Market on Fire
}

\author{
Tom Slayton ${ }^{1}$
}

\begin{abstract}
The world rice market was aflame last spring and for several months it looked as if the trading edifice that had exhibited such resilience over the last two decades was going to burn to the ground. World prices trebled within less than four months and reached a 30year inflation-adjusted high. Many market observers thought the previous record set in 1974 would soon be toast. The fire was man-made, not the result of natural developments. While the governments in India, Vietnam, and the Philippines did not to set the world market on fire, that was the unintended result of their actions which threatened both innocent bystanders (low-income rice importers as far away as Africa and Latin America) and, ultimately, poor rice consumers at home. This paper describes what sparked the fire and the accelerants that made a bad situation nearly catastrophic. Fortuitously, when the flames were raging at peak intensity, rain clouds appeared, the winds [market psychology] shifted, and conditions on the ground improved, allowing the fire to die down. It remains to be seen, however, if the trading edifice has been seriously undermined by the actions of decision makers in several key Asian rice exporting and importing countries. In describing the cascading negative effects of these seemingly rational domestic policies, this paper aims to help policy makers in the rice exporting and importing nations to avoid a repeat of the disastrous price spike of 2008.
\end{abstract}

\footnotetext{
${ }^{1}$ The author is Visiting Fellow, Center for Global Development (CGD), Washington, DC. An initial draft of this paper was presented at the International Workshop on Rice Policy and Food Security in Asia, Chiang Mai, Thailand, February 10-12, 2009, sponsored by the Food and Agriculture Organization of the United Nations. FAO support for preparation of the discussion draft and participation in the Workshop is gratefully acknowledged, as are comments from David Dawe of FAO and Peter Timmer and Nora Lustig of CGD. The views expressed are solely those of the author and not those of CGD or FAO.
} 


\section{Rice Crisis Forensics: How Asian Governments Carelessly Set the World Rice Market on Fire}

Politics Not Supply \& Demand Fuel Rice Crisis. On May 1, 2008, the world rice market was engulfed in flames and it looked as if the trading edifice that had exhibited such resilience over the last two decades was going to burn to the ground. Contrary to the view of many observers, the fire was man-made, not the result of natural developments. Only two weeks earlier, the Philippines paid as much as $\$ 1,220$ CNF for $25 \%^{2}$ - an increase of over $\$ 500$ in just over a month and the trade was speculating that prices might reach $\$ 1,500-1,600$ in a National Food Authority (NFA) tender which was to be held within a week's time. Prices were leaping higher so fast that the ability to capture these changes had long since broken down. The April NFA purchases equated to FOB values of Thai $100 \%$ B of $\$ 1,100$ - nearly three times the $\$ 375$ prevailing at the opening of the year and an inflation-adjusted high of 30 years. It appeared that the previous record set in 1974 would soon be toast.

Thai $100 \%$ B Prices \& Export Restrictions

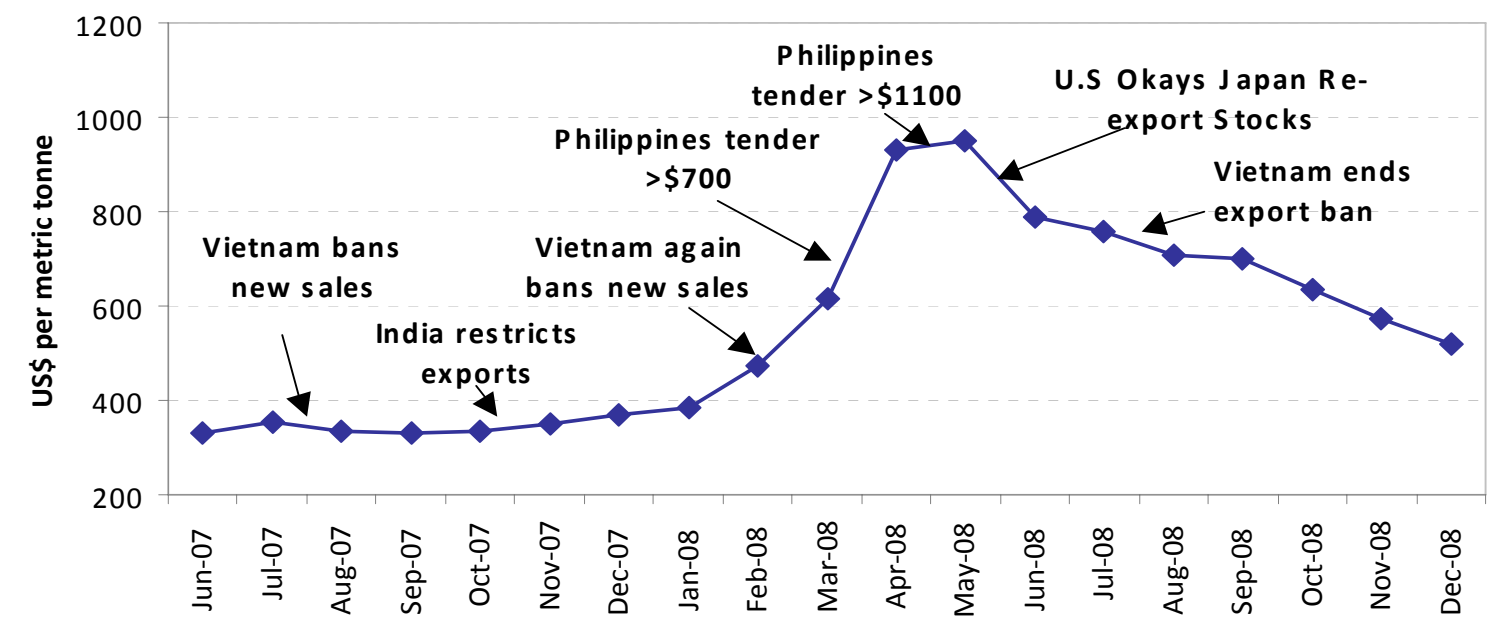

Fortuitously, when the flames were raging at peak intensity, rain clouds appeared, the winds [market psychology] shifted, and conditions on the ground improved, allowing the fire to die down. NFA's May 5 tender ended up being scrapped and the Philippines ostensibly withdrew from the market as a commercial buyer.

\footnotetext{
${ }^{2}$ The percentage of broken kernels is one of several quality factors considered by traders. The larger the share of brokens, the lower the quality (and price) of the rice. (Other quality factors include grain length, the kernel shape, grain appearance, and cooking characteristics. In addition, grade standards vary by country. In Thailand, for example, $100 \%$ B is a premier grade with less than $5 \%$ brokens. For a description of the world rice market and its market segments, see "Pieces of the World Rice Market Puzzle" by Tom Slayton, a paper presented at IBC Asia’s $3^{\text {rd }}$ International Rice Conference, Phuket, Thailand, October 1998.
} 
Within just over a week, the U.S. had publicly given Japan permission to re-export all of its imported rice stocks of over 1.5 million tons, Malaysia booked 200,000 tons of Thai rice at FOB prices equating to $\$ 980$, and Pakistan affirmed that it had an additional 1 million tons available for export. Indeed, with the passage of another month, NFA had covered its needs in quiet, direct negotiations at prices which were more than $\$ 275 /$ ton below that paid in mid-April and that same day Vietnam canceled its export sales ban. By mid-December 2008, Thai 100\% B reached a low of $\$ 515$ and Viet $25 \%$ had fallen to $\$ 300$. As we sift through the ashes in the aftermath of this conflagration, it is unclear how seriously the world rice trading edifice has been undermined. Most certainly, though, a number of key players are taking steps to either increase domestic rice output or invest in production in overseas markets.

The world rice crisis of 2008, while coinciding with a global "food crisis," deserves a separate forensic analysis. (World wheat prices had already peaked in mid-March, but it was soaring rice values which put the global food crisis on the front pages of the popular press and on TV screens around the world.) Unlike the "food crisis" enveloping the other grains and vegetable oils, biofuels, changing diets in China and India, major weather anomalies, extremely tight stocks:use ratios, and "hot money" in the futures markets were not key drivers in the soaring world rice prices. Indeed, the rice crisis occurred during a period of record world production and not especially tight stock levels. After decades of orderly performance and increasing confidence in the reliability of the trading system, the world rice market became more volatile due to a combination of the following factors:

- Export restrictions by India and Vietnam -which accounted for $34 \%$ of all exports in 2007 as the \#2 and \#3 exporting countries - were accompanied by outright bans in Cambodia, Egypt, and other origins;

- Rising oil/petrochemical prices;

- A weaker dollar;

- Ill-considered government policies in a number of countries, especially the Philippines; and,

- A growing, self-fulfilling speculation that prices were heading much higher.

While rising prices for oil/petrochemical ${ }^{3}$ and the weak dollar contributed to the rice price spike, the focus of this paper is on the more critical importance of

\footnotetext{
${ }^{3}$ Oil prices, which averaged \$61/barrel in December 2006, soared to $\$ 90$ averaged in December 2007 and peaked in July 2008 at over \$145/barrel. The rise in rice prices was initially less dramatic - Thai $100 \%$ B averaged \$376/ton in the last month of 2007 - an increase of $\$ 63$ over that experienced one year earlier, but then exploded to over $\$ 1,200 /$ ton in late April and early May 2008. During the same time periods, wheat shot up from \$204/ton to almost \$369 before peaking at \$532/ton in March 2008. The role played by other commodities is less clear cut. For an argument on the role of other commodities in influencing world rice
} 
political decisions made by Asian policy makers. Much of the responsibility for the current crisis is due to ill-considered government policies in India and Vietnam which fed the flames, as well as panicked buying by the Philippines - which was akin to throwing gasoline on the fire. While picking up much of the slack created by the interruption in export shipments out of India and Vietnam, Thailand also contributed to the market's nervousness by talk of a rice exporter cartel and its unwillingness on a timely basis to dispose of its surplus government-held stocks.

\section{India Sets Market On Fire With A “Starve Thy Neighbor” Policy}

Failed Policies \& Electioneering Spark Fire In World Rice Market. While the Indian government defends its grain export restrictions by claiming that it was merely trying to protect its citizenry from rising world prices, upon closer examination it is clear that the Indian government's own actions propelled domestic grain prices higher as the country's politicians have continued to recklessly pursue domestic electoral expediency instead of sound food policies. Following a "temporary" cut in release prices of one-fourth in 2001 to the near-poor, the central government has failed to raise its Public Distribution System prices over the last seven years. This, combined

\begin{tabular}{|c|c|c|c|c|}
\hline \multirow[b]{2}{*}{ FY } & \multicolumn{3}{|c|}{ Subsidy } & \multirow[b]{2}{*}{$\begin{array}{c}\text { Subsidy } \\
\text { \$ Bil. }\end{array}$} \\
\hline & Rice & $\begin{array}{l}\text { Wheat } \\
\text { MMT }\end{array}$ & Total & \\
\hline ’07/08 & 25.2 & 12.2 & 37.4 & 8.58 \\
\hline ’06/07 & 25.1 & 11.6 & 36.7 & 5.96 \\
\hline ’05/06 & 25.0 & 16.1 & 41.1 & 5.73 \\
\hline '04/05 & 23.1 & 17.3 & 40.4 & 6.40 \\
\hline ’03/04 & 22.3 & 16.3 & 38.6 & 6.25 \\
\hline ’02/03 & 16.2 & 12.8 & 29.0 & 6.00 \\
\hline ’01/02 & 12.6 & 6.8 & 19.4 & 4.34 \\
\hline ’00/01 & 10.0 & 4.8 & 14.8 & 2.99 \\
\hline
\end{tabular}

Note: Excludes grain sold under Open Market Sales and for export purposes.

Source: Ministry of Finance, Ministry of Food with successive increases in the size of the rations (from 10-25 kg/family/month depending on the program - to $35 \mathrm{~kg}$ ) resulted in a dramatic swelling of the government's sales of subsidized grain to the poor and near-poor. ${ }^{4}$ While India's governments - both at the state and national levels - jockey for the votes of the poor by providing grain at increasingly subsidized prices, they at the same time are sharply hiking the government-set prices paid to growers with the result that the food subsidy may climb to $\$ 12.0$ billion in Indian fiscal year 2008 - an increase of

prices, see "Causes of high food prices” by Peter Timmer, Chapter 2.3 Asian Development Bank's Development Outlook Update, September 2008.

${ }^{4}$ Releases reached a peak of over 41 million tons in 2005/06, before anti-fraud efforts resulted in 6.5 million bogus ration cards being canceled. While this initially resulted in a 4.4 million ton drop in subsidized grain sales, last year's releases edged up a further 760,000 tons to 37.4 million tons. Source: Annual Report 2007/08 of the Department of Food and Public Distribution, Ministry of Consumer Affairs, Food and Public Distribution. 
45\% over last year's level and up 300\% from the fiscal 2000 level. $^{5}$ (In addition, India's farmers benefit from subsidized fertilizer, power, and irrigation water.) Given India's Malthusian pressures, these policies are akin to smoking in an oil refinery.

The bankruptcy of these policies became clear in 2007. Seeking to avoid political recriminations in the lead up to provincial and national elections, as well as rising domestic food prices, ${ }^{6}$ the Indian government decided to pursue a "starve thy neighbor policy" - curtailing wheat imports and filling the void created in the country's food balance sheet by banning non-Basmati rice exports. This, in turn, triggered export restrictions and hoarding in other countries. Beginning in October 2007, India initially stopped all non-Basmati exports, replacing it three weeks later with a series of ever-higher minimum export prices (MEP) that were set prohibitively above world price levels. ${ }^{7}$ Then India, once again, reverted to an outright ban on April 1, 2008. ${ }^{8}$ India, the source of 5.3 million tons of nonBasmati rice exports in 2007 out of total world trade of 32.1 million tons, had exited the market leaving a gaping hole and soaring world prices. While some exemptions to the ban were permitted, especially to Bangladesh, the trade generally expected a shortfall in Indian exports of 3.5-4.0 million tons. ${ }^{9}$ When

\footnotetext{
${ }^{5}$ The Financial Express, November 27, 2008.

${ }^{6}$ According to USDA,"What is driving India's grain export ban now is more politics rather than economics, as elections in several important states such as Madhya Pradesh, Rajasthan, Chhattisgargh, and Delhi are due before November this year and the national election in May next year. Traditionally, food inflation plays a significant role in deciding the election outcome as high food prices impact the livelihood of aam aadmi (common man), the vote bank that spends more than half of their income on food." Source: “Indian Rice Export Imbroglio,” unpublished USDA report dated May 21, 2008.

${ }^{7}$ The first MEP on October 31 was set at $\$ 425$ or $\$ 100 /$ ton above prevailing Pakistani $25 \%$, but in late December it was raised to $\$ 500-\$ 150 /$ ton above FOB Karachi values. On March 9, 2008, the MEP was boosted to $\$ 650$ or $\$ 190$ over Pakistani $25 \%$ quotes.

${ }^{8}$ Curiously, the government at the same time imposed a MEP on Basmati rice - even though this rice is only eaten by the middle and upper classes. Before being trimmed in mid-January 2009, the MEP for Basmati was \$1,200/ton PLUS an export tax of Rs 8,000/ton (equal to \$160 at then current exchange rates). With the dramatic increase in 2008 Basmati sowings in response to the previous season's lofty prices, Indian exporters of Basmati have seen their market share melt as their Pakistani competitors beginning in late 2008 were no longer burdened with MEPs and have enjoyed a dramatic depreciation of the Pakistani currency vis-a-vis the Indian Rupee.
}

${ }^{9}$ India on December 1, 2007, agreed to supply Bangladesh 500,000 tons under a Government-toGovernment (G-to-G) contract and two months later agreed to a price of \$399 CNF (with discounts and premiums based on the delivery mode). India, however, supplied only 100,000 tons at this price and eventually the balance was contracted at $\$ 430 \mathrm{CNF}$ on April 3, 2008. The later contracts provided for shipment within 60 days of the opening of the letters of credit, but the shipments were only completed in December 2008.

USDA initially forecast a 1.8 million tons decline in exports ("India Grain \& Feed Quarterly Lock-up Report - November," dated October 26, 2007), but revised this to a decline of 3.5 million tons as the 
export restrictions were initiated in October 2007, the international rice traders, by and large, could only turn to Thailand and Pakistan to cover their needs as Vietnam was withdrawn from the market as a seller. By the time the April 2008 ban was announced, Karachi was largely sold out - effectively leaving only Bangkok as a trading venue. ${ }^{10}$

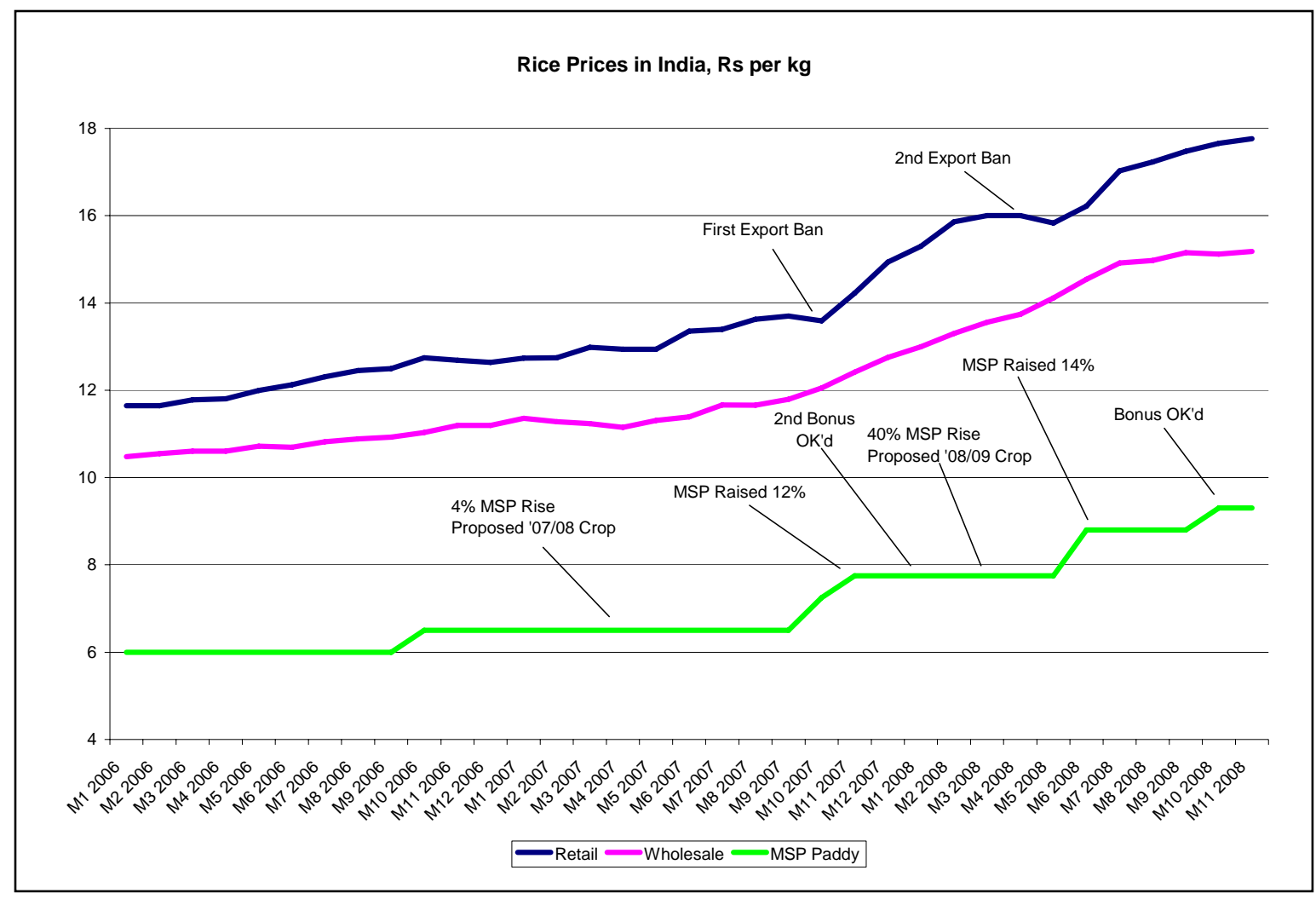

India Burns Own Fingers. Ironically, most of the increase in local Indian grain prices has been "self inflicted." The Indian government had increased the minimum support price (MSP) for the 2007 wheat crop by almost $30 \%$ and then sweetened the rice MSP by $19 \%$ rather than the $4 \%$ recommended by the Commission for Agricultural Costs and Prices (C.A.C.P.). After all, 2008 was going to be an election year and happy farmers make happy voters. At the time when the rice export restrictions were first introduced in October 2007, nominal retail rice prices were "only" 9.6\% above year-earlier levels, but the large support price increases for the new Kharif (main) crop and agitation for even bigger

magnitude of India’s 2007 export volume became apparent. ("India Grain \& Feed Quarterly Lock-up Report - May,” dated May 9, 2008).

${ }^{10}$ Thai exports to Africa surged to over 1.3 million tons during October-December 2007 (almost 470,000 tons above the average movement during 2002-06) and further climbed to over 1.6 million tons during the first quarter of 2008 (more than 875,000 tons above that averaged in the earlier 5-year period). 
increases sparked rising local prices. ${ }^{11}$ By July 2008, retail prices were running more than $27 \%$ ahead of year-earlier levels.

We Are Very Comfortable, But So What? World rice prices were kept on edge during the second half of 2008 as trade and press reports circulated that the Indian government was entertaining proposals to lift either the export ban or allow significant exemptions to the restrictions. In the end the government refused to budge, coming up with a succession of reasons on why it should maintain the export ban on non-Basmati. Initially it said that it needed to gauge the performance of the monsoon. After the monsoon proved to be normal, the economic ministers averred that they needed to wait until November when the size of the Kharif crop could be assessed. Despite a record 2008/09 wet season rice crop in hand (85.4 million tons - up 2.8 million tons over last season) and foodgrain stocks rebuilt to substantially above buffer stock norms, the Indian government as of early 2009 continues to refuse to lift the export ban on nonBasmati rice despite repeated commercial and diplomatic entreaties by its neighbors and customers. In early November 2008, the economic ministers claimed that the ban could not be lifted as long as the country was experiencing double-digit inflation. ${ }^{12}$ But would the lifting of the ban be inflationary?

Record rice and wheat crops in 2007/08 (which shattered by 10 million tons the prior year's unprecedented food production level) and export restrictions have powered huge sales to the Food Corporation of India and allowed the government to rebuild its grain stocks to very comfortable levels. ${ }^{13}$ In fact, India has now built a five million ton "strategic reserve" for foodgrains on top of its buffer stock norms, including 2 million tons of rice. Carryover stocks of government-held rice on October 1, 2008, reached 7.9 million tons -2.7 million tons above the buffer stock norm and 2.4 million tons above year-earlier levels. Wheat stocks as of the same date reached 22 million tons - double the buffer stock norm - and the agriculture minister announced that India would set aside two million tons of

${ }^{11}$ Beginning at least in 1988, the MSP for wheat was set at a modest premium to that for paddy. During the five years beginning 2001, the premium averaged $8.2 \%$. In 2006, though, the premium surged to almost 23\% and in October 2007 the wheat price was boosted from Rp 8,500/ton to Rp 10,000 bringing the MSP premium for wheat to rice to over $48 \%$. These calls by rice growers for a significantly higher MSP were abetted by a February 2008 recommendation by India's C.A.C.P. that the MSP for the 2008/09 rice crop be raised $40 \%$ to Rs 10,500/ton. Delhi's subsequent decision to not accept the C.A.C.P.'s price recommendation - going instead, eventually, with an increase of "only" $20 \%$ proved to be highly unpopular with India's rice farmers.

${ }^{12}$ With inflation having fallen to 3.0\%, the Indian government on March 5, 2009, once again, rejected a proposal to partially lift the ban on non-Basmati rice exports.

${ }^{13}$ The government's domestic rice purchases reached an unprecedented 28.5 million tons in 2007/08, surpassing the previous record of 27.7 million tons set in 2005/06 and exceeding year-earlier deliveries of 25.1 million tons. 
wheat for export to meet requests made through diplomatic channels. ${ }^{14}$ By year's end, government-held foodgrain stocks swelled by 5.5 million tons to reach 35.4 million tons (including 17.4 million tons of rice) ${ }^{15}$ and are projected to reach a near record 52 million tons (including 19 millions tons) by June 1, 2009. ${ }^{16}$

When the decision was made to extend the rice ban in late 2008, new crop deliveries were running well ahead of the record 2007 pace, producing a "dire need for storage space" in Punjab. ${ }^{17}$ As of mid-February 2009, government purchases of rice were running $18 \%$ ahead of the previous year ${ }^{18}$ - on track to set a new record of 30 million tons ${ }^{19}$ - and inflation was falling rapidly, but the economic cabinet, once again, rejected a proposal to lift the export ban on nonBasmati. The government has even been slow to respond to the pleas by India's Basmati exporters who vociferously complained that they have lost significant market share to Pakistan due to the high MEP and export tax. Only on January 20, 2009, did India end its export tax on Basmati and lowered the MEP from $\$ 1,200 /$ ton to $\$ 1,100$. It is, however, unlikely to fully lift the ban on non-Basmati exports before the parliamentary election which will be held April 16-May 13, 2009.

The Background: From Bounty To Bust In Just 5-6 Years. With governmentowned warehouses overflowing with surplus foodgrains which were literally rotting, India started to subsidize the sale of these stocks into the world market. Beginning with wheat in 2000, India extended its export campaign to rice the following year. In 2002, India emerged as the world's second largest rice exporter, shipping an unprecedented 6.9 million tons overseas - an increase of 5.0 million tons in a single year. While rice exports subsequently eased as the government

14 http://finmin.nic.in/stats_data/monthly_economic_report/2008/indoct08.pdf. The agriculture minister's statement is reported by Reuters "Govt to sell rice in open market, stocks ample," November 6, 2008. The agriculture minister's statement is reported by Reuters "Govt to sell rice in open market, stocks ample," November 6, 2008.

${ }^{15}$ http://fciweb.nic.in/stock_management/stock_management.htm The buffer stock norm for that date is 20.0 million tons, including 11.8 million tons of rice. Source:

http://fciweb.nic.in/storage_management/Buffer_Stock_Norms_htm

16 “India Grain and Feed Annual 2009,” USDA report, February 20, 2009.

${ }^{17}$ Tribune News Service, December 5, 2008.

${ }^{18}$ As of February 11, 2009, procurement approached 21.8 million tons. Source: "India's rice procurement up 13.48\%," Commodity Online, February 13, 2009. Two months earlier, FCI officials were quoted in the press as saying a new record will likely be established in 2008/09. Source: The Hindu Business Line, December 3, 2008.

19 “India Grain and Feed Update 2009,” USDA report dated January 14, 2009. 
pulled back from its stock disposal effort in August 2003, India remained a key origin in the world rice trade - vying with Vietnam as the world's second largest exporter.

With government release prices for the poor unadjusted since $2001^{20}$ and the export efforts, the government reduced its excess grain stocks in short order especially for wheat. In the aftermath of a poor wheat crop in 2003, the government began replacing wheat with rice in its domestic feeding efforts for the poor and near-poor, putting additional pressure on its rice inventory. Weatherrelated damage to the 2006 wheat crop and resulting wheat imports in 2006/07 (April-March) of 6.7 million tons, however, set off a firestorm of criticism by the political opposition and pundits in a country that prides itself for having outgrown foodgrain imports.

With rising world wheat prices, India was faced with wheat import values that were above the prices that its rice exporters were fetching. Seeking to avoid a repeat of this criticism in the lead up to domestic elections, the Indian government chose to minimize its wheat imports, maximize local grain procurement, and discourage rice exports - all with the ostensible goal of dampening food inflation. India's policies reduced its wheat imports from the much larger world wheat market to only 1.8 million tons in the year ending March 2008 and no imports are envisioned in 2008/09.

\section{Vietnam Adds To The Supply Shock}

Profits, Not Politics, Fueled Vietnam's Contribution To World Price Surge. While Indian electioneering sparked the 2008 world rice crisis, Vietnam's policies were critical in adding fuel to the fire. Vietnam's fears of shortages due to weather-related losses in the Red River Delta caused by a bitter cold wave which began in mid-January and long standing inflationary sensitivities led to a trade policy which largely banned sales to the international rice traders for almost a year, forcing the trade to pay ever-higher prices in Bangkok. ${ }^{21}$ Vietnam's policy of limiting participation in the NFA tenders also helped to propel world prices to

\footnotetext{
${ }^{20}$ With release prices frozen and support prices increasing by $57 \%$ (paddy) to $61 \%$ (wheat), India's food subsidy has ballooned over the last seven years. This has created tremendous incentives for venal officials to engage in wholesale "leakage" of these stocks to domestic traders and exporters.

${ }^{21}$ Up until June 18, 2008, export sales, with the exception of contracts with "reserved" customers and overseas orders of glutinous and fragrant rice, were banned except for a narrow window running from January 18 through February 4, 2008.
} 
near-record highs. ${ }^{22}$ These higher world prices caused by Vietnam's market interventions eventually resulted in a blowback as local speculators jumped into the domestic rice market causing prices in Ho Chi Minh City (HCMC) to double within the course of a weekend in late April. By the time that local prices cooled, international demand for Vietnamese rice had largely disappeared, resulting in huge unsold stocks of expensive high quality rice for which the provincial exporting companies could not find a home. Facing interest rates of $19 \%$ and prohibitively high MEPs, the provincial food exporters largely refrained from further purchases of high-moisture summer-autumn rice, contributing to a crash in domestic values during August-November 2008 that resulted in large losses to farmers and lost export earnings.

The rice market in Vietnam is both an opaque and "directed" economy. With a goal of ensuring adequate local stocks, policy makers often regulate the country's exports by setting sales quotas and attempt to enforce MEPs. In a typical year, the export sales quota has been reached by late summer and a new quota is not issued until the eve of the harvest of the winter-spring crop in the Mekong River Delta (MRD), which typically begins in late February. During the intervening months, the execution of previously approved contracts is allowed, but new sales are not. The government further intervenes in the market by "reserving" certain export markets for the two Vinafoods, which are state-owned enterprises.

\section{No Surprise, But Vietnam Fails To Deliver NFA's Rice On Timely Basis.} In 2007, the export sales quota was reached by July 21 and no further supplements to the quota were issued. While new sales were still "banned," however, Vinafood 2 and selected provincial food exporters were permitted to participate in NFA's December 2007 tender. This, combined with the contracts concluded in NFA's January 2008 tender, totaled over 700,000 tons. With carryover stocks limited and

\begin{tabular}{|c|c|c|c|c|c|}
\hline \multicolumn{6}{|c|}{$\begin{array}{r}\text { Table 2. Vietnam: Local Prices th } \\
\text { NFA Tenders (\$/ton) }\end{array}$} \\
\hline & & \multicolumn{3}{|c|}{ Tender Results } \\
\hline \multirow[b]{2}{*}{ Date } & \multirow[t]{2}{*}{ Paddy } & \multirow[t]{2}{*}{$25 \%$} & \multirow{2}{*}{$\begin{array}{l}\text { Qty } \\
\text { TMT }\end{array}$} & \multicolumn{2}{|c|}{ Price Sold } \\
\hline & & & & CNF & FOB \\
\hline $12 / 21$ & 221 & 328 & 411 & 410 & 362 \\
\hline $1 / 29$ & 236 & 346 & 300 & 481 & 433 \\
\hline 3/11 & 269 & 408 & 200 & 716 & 658 \\
\hline $4 / 17$ & 285 & 447 & 80 & 1,200 & 1,070 \\
\hline $5 / 5$ & 344 & 513 & & aborted & \\
\hline $6 / 20$ & 301 & 476 & 360 & 935 & 805 \\
\hline \multicolumn{6}{|c|}{$\begin{array}{l}\text { Note: The local price for } 25 \% \text { is bulk warehouse } \\
\text { FOB HCMC. Estimated Fobbing costs in mid- } \\
\text { October were } \$ 36-40 / \text { ton. Tender results refer to } \\
\text { Viet sales to NFA of } 25 \% \text {. FOB values reflect } \\
\text { prices actually paid to provincial exporters with } \\
\text { the exception of June } 20 \text { which is an estimate. }\end{array}$} \\
\hline
\end{tabular}

\footnotetext{
${ }^{22}$ Without prior permission from the Vietnam Food Association (VFA), provincial food companies are prohibited from selling directly (or indirectly through international traders) to NFA, Bulog, Bernas, and Alimport as these markets are reserved for Vinafood 2. Iraq has traditionally been reserved for Vinafood 1, but this prohibition was not enforced in 2008. In 2007, these "reserved" sales accounted for over $70 \%$ of all exports and played a key role in the losses suffered by the provincial food companies. As a result, it was decided that these "reserved" sales would be reduced to only $60 \%$ of total exports.
} 
given the crop calendar, both Manila and Hanoi "knew" that Vietnam would not be able to perform its contracts on a timely basis, but the contracts were inked anyway.

Expecting local prices to decline under harvest pressure as it covered the bulk of its sales, Vietnam aggressively sold 411,000 tons in the December tender at what were essentially the equivalent of then prevailing local prices. The general ban on export sales was (briefly) lifted in mid-January, but the expected seasonal decline in domestic prices did not occur. By the time that NFA re-entered the market at the end of the month, local prices had risen $\$ 18$ /ton over the intervening five weeks, prompting Vinafood 2 to hike its price in the new tender by over $\$ 70 /$ ton and limiting its offers to 300,000 tons out of the 550,000 tons being sought by the Philippines.

Between the two tenders, Vietnam had sold 164,000 tons for January arrival in the Philippines, 178,000 tons for February, and 279,000 tons for March delivery. Against the nearly 622,000 tons sold for first quarter arrival, Vietnam is estimated to have supplied only slightly more than 321,000 tons.

The Export Sales Ban Is Re-instated. The higher prices bagged in the Philippines, however, helped to propel local prices higher - sinking any uncovered commitments from the first tender to well below the market. With local prices soaring on the eve of what proved to be a record winter-spring harvest ${ }^{23}$ and Hanoi concerned about the extent of crop losses in the north, a new ban on export sales was instituted so that Vinafood 2 would not have to compete with firms seeking to cover rice sold to the international traders. (Initially, it was not clear how long the prohibition was to last, then market participants were advised that this ban was to be lifted by the end of April, which was subsequently extended through June, and then was only lifted after a large G-to-G sale was negotiated with the Philippines.) The export bans were not successful at capping domestic prices, however, and soon the country's exporters found themselves forced to cover their new contracts at prices substantially above their sales prices.

With the delay in shipments out of Vietnam, NFA's inventory fell to the equivalent of 8 days supply by early February - just over half of the 15 day norm. President Arroyo personally and very publicly urged Vietnam in late February to promise to sell at least another 1.0 million tons, but Hanoi, uncertain of crop losses, initially resisted making this commitment. When NFA returned to the market in mid-March for an additional 550,000 tons, Vinafood's appetite for additional large sales was not keen as local prices had jumped by $\$ 62 /$ ton in the

\footnotetext{
${ }^{23}$ The winter-spring harvest in the MRD, which recharges the country's exportable surplus, ended up rising to record 9.7 million tons - more than 570,000 tons above the prior peak reached in 2007.
} 
intervening forty-plus days, resulting in both its December and January contracts being "under-water." (Politically, Vietnam probably could not have passed on participating in the March 11 tender.) According to trade reports, only at the last minute Vinafood 2 decided to more than double its planned offer of 90,000 tons. It offered to sell 231,000 tons, including 200,000 tons of $25 \%$ at a weighted average price of $\$ 716 \mathrm{CNF}$ or almost $50 \%$ above its last sales price and far above prevailing prices. This, of course, resulted in prices in the MRD further heating up. Adding to the rising temperatures, it was disclosed on March 26 that Vietnam had committed to eventually sell the Philippines a total of 1.5 million tons or the equivalent of another 558,000 tons.

Hanoi Cuts Export Target, But Does Not Rein In Vinafood. Citing concerns about galloping inflation, a need to deliver larger than normal shipments to the north as unseasonably cold weather destroyed large acreages in that region, diminished imports from Cambodia, and large outstanding sales to the Philippines which were made at prices that now involved large losses for exporters, the Vietnamese government in late March cut its export target to 3.5-4.0 million tons. Amid press reports that local rice prices had soared $60 \%$ higher in recent months, it was reported that an export tax of $10-15 \%$ was under consideration. The rice market, however, was poised to heat up even further. With another large NFA tender already announced for the first week of May, NFA returned to the market on April 17 for 500,000 tons, but managed to buy less than 365,000 tons, including only 80,000 tons of Viet $25 \%$ at an average CNF price of $\$ 1,200 /$ ton $^{24}$ or $\$ 484$ higher than the sales price of just one month earlier! News of the unprecedented prices paid by the Philippines set the rice market ablaze - both globally and in Vietnam. When news of the sales circulated within the MRD, local traders - including those involved in trading other commodities - jumped into the market as buyers and within a week there was a run on rice in HCMC. Within the course of a two-day period, local prices doubled as rice disappeared from the markets within the city.

Amid speculation that Vietnamese rice would be offered at $\$ 1,400$ or above, NFA's May tender was (deliberately?) aborted as Vinafood 2 was the only participant and it did not submit the requisite "sovereign guarantee." As a result, its envelope was not opened and the Philippines indicated that it was pulling back as a buyer. NFA's ostensible withdrawal from the market allowed the fire burning in the Vietnamese rice market to die down. Only in mid-June, after a G-to-G sale of 600,000 tons $^{25}$ was concluded and nearly 11 months after the export restrictions

\footnotetext{
${ }^{24}$ Vietnamese firms sold a total of 100,875 tons, but one firm elected to source its contract out of Pakistan.

${ }^{25}$ Vinafood sold 60,000 tons $5 \%, 180,000$ tons $15 \%$, and 360,000 tons of $25 \%$ at an average price of $\$ 940$ CNF. No price breakdown by quality was disclosed and the price estimate in Table 2 is based on the value differentials prevailing in the local market at the time of the sale.
} 
were first announced, were the provincial food companies ostensibly allowed to resume their export sales efforts, albeit they faced a hurdle of a prohibitive MEP of $\$ 800$ for $5 \%$ and the approach of what proved to be a record summer-autumn crop. ${ }^{26}$ Further complicating the exporters' efforts, many farmers had planted short duration varieties with poor grain quality characteristics. ${ }^{27}$

With the lifting of Vietnam's ban on new contracts, the slide in world prices accelerated - outpacing VFA's lowering of the MEPs. With insufficient export demand to absorb the new crop arrivals, local paddy prices began to tumble. From a high of \$340/ton in mid-May, Viet paddy values in the MRD plunged \$85/ton over the course of the next three months until the prime minister gave oral instructions on August 7 to the Vinafoods and the provincial food companies to buy 600,000 tons of rice at above-market prices which were to provide at least a $40 \%$ premium to the farmers' cost of production. With prevailing interest rates approaching $20 \%$ p.a. and MEPs continuing to be set at levels that were a hindrance to concluding export contracts, these stocks ended up being an ongoingdrain on the profits of the firms which made the purchases.

Only beginning in late September 2008 were the MEPs set at levels that proved to be attractive. By this time, though, MRD paddy prices were continuing to collapse and the additional overseas sales were insufficient to provide market support. By the end of October, paddy values were in free fall, spiraling to below \$188. This resulted in Hanoi's instructions for the exporters to buy an additional 300,000 tons (this time without any directive on price levels). While prices stabilized temporarily, by the end of November paddy had declined an additional $\$ 19 /$ ton, prompting heated exchanges in the national assembly of how the government had incorrectly forecast both the size of the domestic harvests and world price trends. The prime minister on November 28 instructed the two Vinafoods to buy 1 million tons of paddy (or 600,000 tons of milled rice) and provided interest-free financing from the state-owned Bank for Agriculture and Rural Development (Agribank) at a time when prevailing interest rates were $15 \%{ }^{28}$ (It is unclear, however, how active purchases have been under this instruction.)

\footnotetext{
${ }^{26}$ The summer-autumn crop in the MRD is estimated to have approached 9.4 million tons, almost 350,000 tons above the record 2007 harvest. Re the MEP, the VFA only issued a price for 5\% -- effectively prohibiting the sales of other qualities.

${ }^{27}$ In some provinces as much as $40-60 \%$ of the acreage was planted with IR50404. Source: "Worries about rice prices," VietNamNet Bridge, dated September 30, 2008. IR50404 can yield 7-8 tons/ha with a growing season of 95 days, but the rice produced has a high chalky kernel content and a large percentage of small brokens when milled. According to the trade, this variety can only produce export grade $25 \%$ when mixed with other rice.

28 "PM demands 1 mln ton rice purchase,” VietNamNet Bridge, dated November 29, 2008. Also, “Agribank to help exporters buy 600,000 tons of rice,” Than Nien Daily, dated November 30, 2008.
} 
The Background: Market Manipulation Is SOP. Policy makers in Hanoi attempt to control Vietnam's rice economy via the VFA - helping to partially shield the government from any unpopular decisions. VFA is an "association" in name only. The VFA is actually an extended arm of Government administering the rice export management regime (export quantities, minimum target export prices, etc.) on instructions received from the Rice Export Administration Committee. (The committee includes the prime minister, the ministers of agriculture and trade, and the VFA.) The head of Vinafood 2 is the chairman of the association and because of his power in distributing contracts and because Vinafood 2 owns controlling interest in a number of what were previously provincially-owned food companies (under the so called "mother-daughter" system), it is a rare occurrence when he is over-ruled. Both Vinafood 1 and Vinafood 2, though, are exempt from the administration of both the quotas and MEPs. Thus, the Vinafoods are able to exploit the export quotas to garner a major share of the exports in any one year.

The role of the MEP is both long-standing and dynamic. At times the MEP is indicative, but periodically the authorities tighten the screws and in some period the screws are tighter than others. In 2008, for example, VFA generally would not approve contracts with prices below the MEP. (Reportedly, though, there were instances where firms that were close to Vinafood 2 were allowed to execute contracts at prices below those posted. Indeed, Vinafood 2's sale to Bernas in midNovember at $\$ 460 \mathrm{CNF}$ - net of commissions at $\$ 420 \mathrm{FOB}$ - was made at a time when the MEP was $\$ 500{ }^{29}$ ) With decisions by VFA being made on an ad hoc basis, there were periods last year when it was not clear what the MEP levels were and others when only a MEP for a single grade was issued. Finally, there is no fixed schedule of when new MEPs will be announced. ${ }^{30}$

\section{The Philippines Dumps Accelerant On The Fire}

Why Local Prices Caught Fire. If India's market exit sparked the crisis and Vietnam's export restrictions further fueled the blaze, the Philippines, acting like a panic-stricken buyer, threw successive barrels of gasoline on the already raging flames. Domestic retail prices, which had been running 9-10\% ahead of yearearlier levels, took off rapidly beginning in March 2008 and by June leaped to $60 \%$ above 2007 levels. There were a number of reasons for the escalating values.

\footnotetext{
29 “Vietnam sells 100,000 tonnes of rice to Malaysia,” Reuters, November 19, 2008.

30 VFA only episodically posts its MEPs on the internet and then in Vietnamese http://www.vietfood.org.vn/vn/default.aspx?c=74
} 
First, government-held stocks by early February (and continuing into March) had reached dangerously low levels because NFA purchased rice that Vietnam was unable to deliver on a timely basis. Second, statements and actions by senior government officials helped to unnerve the public, encouraging long lines and hoarding. ${ }^{31}$ Third, the government's decision on the eve of the dry season harvest to raise paddy procurement prices by $48 \%$ came too late to influence the size of that crop, but put additional upward pressure on local milled rice prices and did not initially result in large tonnages of domestic rice flowing to the government. Finally, NFA's tenders and buying decisions were destabilizing to both the world and local markets.

Some of the government's decisions may, in part, be explained by political considerations, given an election in May 2010 and President Arroyo's poor poll ratings. ${ }^{32}$ The president decided to take a very high profile role in attempting to reassure the public and to contain what became run away domestic prices. Unfortunately, her personal involvement, rather than say that of the head of NFA, in greeting arriving vessels carrying imported rice, touring government warehouses and rice distribution efforts, visiting the courts when persons charged with rice "speculation" were arraigned, etc. undermined assertions that the government had matters "under control." (Similarly unsettling was the secretary of agriculture's ill-advised comment that imports could be cut by 700,000 tons if only restaurants and fast food outlets would reduce their rice servings by half because Filipinos wasted so much rice. ${ }^{33}$ )

Equally important, a number of policy decisions also contributed to the surge in domestic prices. Having the national police raid the warehouses of traders and millers in late March to uncover speculators resulted in what the press reported was a wholesale shutdown of the rice milling industry as mill owners feared that even "normal" stock levels might land them in jail with a sentence of life for economic sabotage. ${ }^{34}$ Similarly unsettling were publicized reports that the government felt it was necessary to use the army and armored transport to deliver

\footnotetext{
${ }^{31}$ On April 3, the minister of justice described the current situation as an "emergency" and advised that stocks were one-third below the targeted level.

${ }^{32}$ According to a Pulse Asia Inc. survey conducted in October 2007, 41\% of the respondents indicated Arroyo was the most corrupt politician in the country's history - outpolling Ferdinand Marcos with 35\%. Source: “Arroyo 'most corrupt' Philippine leader: poll,” Reuters, December 11, 2007. By the spring, her popularity had fallen to $23 \%$ according to another Pulse Asia poll. Source: "Anti-Chinese cracks in Philippine rice bowl,” Asia Times, April 3, 2008.

33 “Halve rice portions, restaurants asked,” Malaya News, March 18, 2008.

34 “Gov’t warned of rice mill closures,” Philippines Inquirer, April 23, 2008.
} 
rice from NFA warehouses to the poor in Manila and within the countryside. ${ }^{35}$ As indicated above, NFA's support price hike in April came too late to influence planting decisions, but acted as a price signal to the trade. Further, NFA failed to deploy the resources to secure any major volume of locally produced rice. In the aftermath of the support price increase, NFA's domestic procurements totaled only 9,000 tons during April- July, begging the question of why the procurement price was raised in the first place.

As the retail prices climbed, the attractiveness of NFA's subsidized rice increased - prompting ever longer lines of people standing in the hot sun in front of a limited number of outlets, waiting to buy small quantities of the subsidized staple. "Televised images of poor people in lines 'create the impression of severe shortage, consumer panic, and an administration that seems to be losing control of the situation,' according to an editorial Friday in the Business Mirror, the country's leading economic newspaper." ${ }^{\text {}}$ The gap also increased the profitability of the widespread practice by well-connected traders of re-processing and/or re-bagging subsidized NFA rice and selling at much higher commercial prices. In January 2008, NFA rice at P $18 / \mathrm{kg}$ was being sold at a P $5.3 / \mathrm{kg}$ discount to other regular quality rice, but by March the gap had jumped to $\mathrm{P} 7.3 / \mathrm{kg}$. With retail prices rocketing to a peak of $P 35.5 / \mathrm{kg}$ in July, the cheapest NFA rice was being sold at just under half of the prevailing prices. (The ADB estimates that NFA's subsidized rice sales resulted in losses equivalent to $2.5 \%$ of the GDP. ${ }^{37}$ )

Overly Aggressive Buying. After high profile, very public efforts in early March to persuade Vietnam to agree to sell an additional 1.0-1.5 million tons (Hanoi at that time agreed only that its total sales to NFA would be 1.0 million tons), the Philippines then sought to calm the local market by disclosing that it planned to buy 2.7 million tons by mid-year, so that there would be surplus stocks. ${ }^{38}$ Then came a flurry of government actions - police raiding warehouses, the government threatening to jail speculators, talk of using the army to guard trucks transporting rice, etc. Heightening market anxiety, the Philippines made repeated efforts to commercially tender for U.S. rice even though the delivered prices would be very

\footnotetext{
35 “Philippines rice shortages cause chaos,” The Australian, April 21, 2008.

36 “Philippines Caught In Rice Squeeze,” Washington Post, April 12, 2008.

${ }^{37}$ The ADB estimates that the consumer subsidy in 2008 reached 31 billion pesos (equivalent to $\$ 695$ million at prevailing exchange rates), up from only 8.7 billion pesos in 2006 and 12.4 billion pesos in 2007. "Effectiveness of Public Spending: The Case of Rice Subsidies in the Philippines," by Shikha Jha and Aashish Mehta. ADB Economic Working Paper Series No 138, December 2008.

${ }^{38}$ One official told the author that the government intended to deliberately over-import in 2008 so that it could minimize imports in the year before the presidential election in order to demonstrate "success."
} 
high. In late March, the Philippines succeeded in negotiating an MOU with Vietnam for 1.5 million tons and the president then publicly pursued an MOU with Thailand.

The nature of NFA's international buying efforts also contributed to higher prices. Rather than using a mix of smaller tenders and direct negotiations to secure its imports, the food authority held a series of what were essentially monthly "mega" tenders each of at least 500,000 tons with terms that favored Vinafood 2. In these tenders, NFA did not appear to be a particularly tough negotiator. For starters, it acceded to a $\$ 70$ hike in the January tender - more than double the extent to which local Vietnamese prices had risen in the intervening five weeks since its first purchases. More telling was NFA's response in the March tender to offers which were about $\$ 150$ above the spot market. Then, instead of rejecting these exorbitant prices, NFA booked all offers. Rather than letting the market take a rest, NFA promptly issued a fourth mega-tender for April 17, again for 500,000 tons - even before asking the successful sellers if they were willing to increase their quantities by $25 \% .{ }^{39}$ With the increase in world prices now taking on a dynamic of its own and with the disclosure that NFA would soon be back as a buyer, it is not particularly surprising that all of the firms declined the request. Of course, NFA's buying behavior tended to confirm suspicions that the government officials - who regularly announced, "We have enough rice stocks," - were not being candid.

NFA's May 5 Tender. Nine days before the April tender the President publicly disclosed there would also be a May tender for 500,000 tons - an announcement that undoubtedly contributed to the stratospheric prices and relatively limited quantities offered on April 17. Although NFA's fill rate in its tenders was deteriorating and the prices it was paying had exploded, the May tender seemed to be designed to limit participation and - by extension - result in even higher prices offered. First, the tender was to be held less than three weeks after the April outing. Second, the tender - which was subsequently increased to 675,000 tons included ultra-spot delivery. While NFA's tenders called for a validity period of 5 business days, which theoretically allowed the Philippines to only award the contracts on May 12, and the sailing time from either HCMC or Bangkok to the Philippines is 5 days, the tender provided for deliveries of at least 202,000 tons which were to arrive by May 31. Finally, NFA replaced its normal provisions for performance and bid bonds with an unconditional, irrevocable "sovereign guarantee" which must be signed by the head of state. As one Singapore-based trader remarked, "I would have to get Lee Kuan Yew to agree to back my offer." Effectively, this restricted the May 5 tender to Vietnam as both the Thai and Chinese governments had refused to participate in any of the prior tenders.

\footnotetext{
${ }^{39}$ Under its standard operating procedures, NFA is permitted to ask successful sellers in a tender to increase their sales quantity by $25 \%$ at the original price offered.
} 
Fearing that world prices would soar to $\$ 1,500 /$ ton or perhaps spiral further out of control, ${ }^{40}$ the World Bank, the Indonesian government, and others urged the Philippines to scrap the tender. Even though the Thai government announced that it would not participate, NFA declined to halt the tender. It was aborted, however, when only Vinafood 2, in the aftermath of the outbreak of "rice fever" less than two weeks earlier, submitted an offer that did not contain the requisite "sovereign guarantee." Under NFA's procedures requiring at least two tender participants, Vinafood's envelope was not opened, but the market speculated that its offer for $25 \%$ was at $\$ 1,400 /$ ton.

After the aborted tender, the Philippines claimed that it had purchased enough rice for the time being. Not only might it only return as a buyer in the fall, but, in any case, it said that it would refrain from paying over $\$ 1,200 /$ ton for any additional purchases. The Philippines, which had already approached Tokyo one week earlier for 60,000 tons of Japanese rice and was pursuing U.S. government financing for additional American rice purchases, ${ }^{41}$ was encouraged by Washington to explore with the Japanese government the idea of obtaining major tonnages of rice that Tokyo had imported. On May 7, The Philippines informally asked Japan if it would provide it with 200,000 tons of its imported stocks. While publicly laying low (helping to calm the world market), the Philippines pursued a G-to-G deal with Vietnam. On June 13, Vinafood 2 offered to sell NFA 600,000 tons and five days later The Philippines disclosed that a contract had been signed at $\$ 940 \mathrm{CNF}$, bringing its total purchases to 2.3 million tons.

The \$71 Million Question. An important unresolved question is why marketing margins in these trades increased so substantially between late December 2007 and the first half of 2008. Table 2 details the CNF prices paid by NFA and the FOB prices passed on to the provincial food companies. After deducting approximately $\$ 30$ for freight and $\$ 10$ for financing, there remains an unexplained gap of $\$ 8 /$ ton in the December and January trades. With the March tender, the gap more than doubled, but it ballooned to $\$ 90$ in both the April and June contracts.

\footnotetext{
${ }^{40}$ A senior economist for the International Grain Council was quoted by Reuters on April 22 as saying that he expected that the May tender would see price of \$1,500-1,600/ton offered. Subsequently, the head of VFA was quoted in the press on May 4 that Vietnamese prices were forecast to increase to $\$ 1,400$.

${ }^{41}$ U.S. long grain rice is normally not competitive in Asian markets on a commercial basis. Not only are FOB values usually well above those in Asia, but freight costs are substantially higher. Asian rice prices had risen so high, however, that the Philippines decided to buy U.S. rice under the GSM 102 commercial guarantee program. Under an April 8 tender, NFA and ended up buying 72,600 tons for June-September shipment at an average price of over \$1,058 CNF.
} 
On April 4, 2008, following a "summit" with government officials and farm experts on how to contain the rice crisis, President Arroyo announced that the government will spend over $\$ 1$ billion to increase rice production to reach selfsufficiency by $2010 .^{42}$ (This goal was subsequently pushed back to 2013.) In August, NFA announced a target of locally procuring 500,000 tons of rough rice before year's end and in October the goal was doubled to 1.0 million tons. By December 2008's close, NFA had secured a record 691,000 tons.

\section{Background: NFA Has Long Relied On Imports Rather Than Local Buying.}

NFA has long relied on imports to fuel its stocks, which are released to control local prices. In 2007, for example, NFA's local purchases totaled only 32,577 tons - less than .2\% of the domestic crop - and during the prior five years NFA's domestic bookings averaged only 191,000 tons or $1.3 \%$ of the harvest. Imports, in contrast, totaled 1.8 million tons in 2007, after having averaged almost 1.5 million tons during 2002-06.

At the beginning of its import buying campaign, NFA always issues a deliberately conservative forecast of its needs. The food agency usually begins buying in December or January and attempts to limit its import arrivals to the first three quarters of the calendar year, as later deliveries would coincide with the seasonal decline in prices occurring with the main crop harvest. For the 2007-08 campaign, NFA initially announced that its imports would fall to 1.4 million tons, at a time when the trade reported that its internal reports indicated it needed to buy 1.9 million tons - the same level of imports as in 2007. Actual needs, though, were closer to 2.1 million tons because NFA's below-market domestic rice sales have been encouraging a shift in demand from wheat and corn to rice.

For decades, unscrupulous - but politically well-connected - traders have bought this rice at the subsidized price, then repackaged and resold it at the higher market price, pocketing a handsome profit.

\section{Thailand Saves The Day, But...}

Thailand proved to be the first line of defense in preventing the world rice trading edifice from being burned down as Bangkok-based traders, in large measure, picked up the slack created by the interruption in exports out of India and Vietnam. If they had not, it is not impossible that prices could have reached the levels occurring in the conflagration of 1972-74 when 100\% B in April 1974 exceeded \$2,700/ton in inflation-adjusted terms. For six consecutive months beginning with October 2007, monthly Thai exports topped 1.0 million tons and

\footnotetext{
42 "Philippines Agricultural Situation Philippines FIELDS Program 2008,” USDA report dated April 21, 2008.
} 
during the subsequent four months sailings averaged a "mere" 914,000 tons. Indeed, over the twelve months ending in September 2008, Thailand exported over 11.7 million tons. ${ }^{43}$

While the extra three million tons originating out of Thailand were critical in creating a fire line and help tamp down the flames, the Thai government could have played a more active role in bringing the crisis under control by releasing its stocks of 2.1 million tons. Further, it heightened market fears by proposing that South East Asian rice exporters should establish a cartel along the lines of O.P.E.C. and by making some unnerving statements.

In February, before the world rice crisis had significantly worsened, a newlyelected government led by Samak Sundaravej, a stand in for former Prime Minister Thaksin Shinawatra (who had been overthrown by the military in 2006 and barred by the courts from office for corruption), assumed the prime ministership as the head of the Palang Prachachon Party (PPP). Despite a call by the head of the Ministry of Commerce's Public Warehouse Organization for the new government to quickly auction off 500,000 tons of its stocks the very week that the new government assumed office, the regime contributed to the chaos both at home and abroad by failing to release virtually any of the stocks that it was holding. This was despite desperate appeals from its exporters who were reported to be losing up to $\$ 200 /$ ton on previously negotiated contracts and/or were demanding contracts be re-negotiated as their local suppliers defaulted on them. Also, the rapidly rising local prices prompted runs on rice at the local hypermarkets amid press reports of farmers having to guard their rice fields lest thieves steal their unharvested crop.

Statements Raise Fears That Thailand Will Exit The World Market. The refusal to unload more stocks was worsened by two statements out of the Ministry of Commerce. First, the vice-minister was quoted in mid-March ${ }^{44}$ as saying that the government was considering imposing export restrictions - for the first time in more than a generation. Then, on March 28, 2008, the minister urged farmers not to sell as he predicted prices would reach $\$ 1,000 /$ ton by June. (He did not specify whether he was referring to Jasmine values or $100 \%$ B.) Then a few days later the manager of the Thai Rice Exporters Association was quoted as saying that due to domestic "rice unrest" the government might restrict exports. Within forty-eight hours, the prime minister, as well as the commerce and finance ministers, were making statements that Thailand had enough rice and that Bangkok would not

\footnotetext{
${ }^{43}$ This was 3.1 millions tons above the export levels averaged during 2002-06.

44 “Ministry May Put Cap on Rice Export Prices,” Bangkok Post, March 18, 2008.
} 
restrict exports. The jittery market, however, was not convinced, especially when Samak proposed a cartel be formed by the region's exporting countries.

Or Jack Up Prices Via A Cartel. At the height of the crisis, the Thaksin 2 government resurrected a proposal that Thailand, Vietnam, Cambodia, and Burma create a rice exporter cartel, the Organization of Rice Exporting Countries (O.R.E.C.). The cartel, first proposed by P.M. Thaksin in 2001, heightened the fear which was already palpable in the market, with the Philippines and international organizations like the Asian Development Bank coming out vehemently against the proposal. While enthusiastically endorsed by Cambodia's prime minister, world public opinion forced Thailand to withdraw the proposal on May 6 - just one week after it had been unveiled. ${ }^{45}$

While the Thaksin 2 government initially decided to release up to 650,000 tons of its stocks to dampen rising local prices, in the end only 1,500 tons was released as a rivalry between P.M. Samak and Minister of Commerce Mingkawan Saengsuwan surfaced. This animosity eventually resulted in Mingkawan's portfolio being changed to that of minister of industry. Meanwhile, the stocks remained locked up and an opportunity to sell major tonnages to the Philippines was lost. ${ }^{46}$

The Grand Race Which Thaksin Lost. With nearly a dozen court cases pending against Thaksin, his family, and the PPP, the Thaksin 2 government's energies were focused on amending the constitution in a manner which would short circuit the pending court cases, including one which resulted in the PPP being ordered December 2, 2008 to be disbanded for fraud committed in the December 2007 election. Faced with the prospect that the PPP might need to go before the voters sooner rather than later and with rice farmers demanding the Thaksin 2 government restore above-market paddy mortgage scheme prices, Samak proposed in June 2008 that the dry season support intervention be set at Baht $14,000 /$ ton (\$420/ton paddy at then current exchange rates) for $5 \%$ rough rice more than double the last support level and 20\% above the market - with a purchasing target of 2.5 million tons. Thai local prices immediately leaped higher by $\$ 125 /$ ton and Thai exporters complained vigorously that the intervention level was too high and would result in $100 \%$ B export prices at over $\$ 800 /$ ton. With such attractive prices, paddy quickly flowed to the government, prompting upward

\footnotetext{
45 “Thailand Grain and Feed OREC 2008,” USDA report dated May 7, 2008.

${ }^{46}$ Samak admitted that a proposal for Thailand to participate in NFA's negotiations for 600,000 tons on June 13, 2008, was removed from the cabinet agenda at his request. ("Rice Exporters Reject PMs Reply," Bangkok Post, June 27, 2008). No strategic or economic rationale was given for this decision which angered Thai exporters and resulted in a significant setback for the kingdom.
} 
revisions in the quantum being allowed to be delivered and supporting export prices at levels that were significantly above what they otherwise would have been. By the time that the program ended in September, 4.1 million tons of rough rice had been pledged.

After Samak was forced to resign in September due to an adverse court ruling, his successor - Somchai Wongsawat, Thaksin's brother-in-law - in October oversaw a lowering of the support price for the 2008/09 main crop to Baht 12,000/ton for $5 \%$ white rice with a procurement target of 8 million tons. At brokens values prevailing at the time, this equated to FOB export prices of $100 \% \mathrm{~B}$ of approximately \$625/ton.

With Crisis Over, Government Releases Stocks. It was only in November 2008 that the government, faced with a lack of available warehouse space and strapped for cash, ended up liquidating both its carryover stocks of 2.0 million tons old crop material plus some 600,000 tons of 2008 dry season crop rice. On November 5, the government offered for sale 3.0 million tons, including 2.3 million tons of both old and new crop non-fragrant rice (ranging from 2004/05 main crop through the 2008 second crop) and almost 7 million tons of Pathum Thani and Jasmine rice (also ranging from 2004/05 main crop through the 2008 second crop.) While the government did not disclose the details of either prices offered or that awarded, it sold almost 1.1 million tons of old crop white rice - mostly $5 \%$ at an average exwarehouse value of $\$ 335$ FOB - and .5 million tons of old crop fragrant rice at an average price of \$448 FOB. According to press reports, the government lost \$209 million at the prices awarded. The government re-tendered on November 28 to sell 1.4 million tons, including 1.2 million tons of white rice $-377,000$ tons of $25 \%$ from the 2004/05 and 2005/06 crops and 807,000 tons of 5\% from the 2008 dry season harvest - and 192,000 tons of fragrant rice, mostly Patum Thani (2008 dry season crop). Reportedly the government awarded contracts on all but .2 million tons, with the $25 \%$ sold at $\$ 225-266$, $5 \%$ at $\$ 399-472$, and the fragrant at $\$ 426$ 511 - at an additional loss of $\$ 85$ million. ${ }^{47}$ Curiously, the minister of commerce issued the order to conclude the contracts the day before the Constitutional Court ordered the Thaksin 2 government be dissolved for voter fraud. ${ }^{48}$ The sales occurring under the November tenders were investigated by the current government for alleged irregularities, but were finally all "cleared" for shipment in late January.

\footnotetext{
47 “Thailand Grain and Feed Intervention Rice Retender Results 2008," USDA report dated December 4, 2008. See also "Govt Stands to lose Bt 10 bn from Rice Bids," The Nation, November 20, 2008 and “Thailand Grain and Feed Intervention Stocks Released 2008,” USDA report dated November 25, 2008.

48 "Thai Govt Sells 1.2 Mln Tonnes Rice to Exporters," Reuters, December 5, 2008. See also "Thailand Grain and Feed Weekly Rice Price Update 2008," USDA report dated December 2, 2008 and "Price shortfall sparks call for scrapping of latest rice bid,” The Nation, December 9, 2008.
} 
Background: Let The Taxpayers Finance The Political Campaigns. Where Thai politicians had traditionally literally paid voters for their votes with cash and other goods, such as rice, Thaksin Shinawatra revolutionized Thai politics by using the public purse to "buy" the ballots of farmers and the poor. Under the Thaksin 1 government, political support from the farmers was secured by large scale government intervention in the paddy market at prices that were significantly above market levels. The mills participating in the price support endeavor had to "pay to play," generating a significant amount of cash for the ruling party. These mills, in turn, would recoup their investment by inter alia adulterating the rice, using the government rice as its working stocks (only replacing the material when inspections or auctions occurred), etc. Given the above-market prices paid and the fraud on-going in the program, the government would hold these stocks off the market for as long as possible and then hold auctions where the rice was often sold at a loss, generating more opportunities for payments. ${ }^{49}$

In the 2005/06 cropping season - after which the military deposed Thaksin as prime minister, farmers delivered 7.5 million tons of paddy to the government. The civilian government installed by the military ostensibly inherited stocks of over 6.75 million tons of paddy or the milled rice equivalent of almost 4.5 million tons. This government slashed the intervention prices by $7-12 \%$ during its first year in power - limiting the deliveries to the government to 3.4 million tons - and disposed of over 2 million tons of stocks by selling it to the trade. ${ }^{50}$

\section{Prices Take On A Life of Their Own As Market Speculation Occurs}

As exporting countries progressively withdrew from the world market, rice importing countries were left to cope as best they could. Over the last decade the world rice market has been stable enough for most countries to reduce their level of rice stocks and use trade as a more efficient stabilization mechanism. With this option seemingly disappearing, many countries felt a need to build domestic stocks, and this extra demand fueled world prices in the short run. Hoarding

\footnotetext{
${ }^{49}$ According to conversations with Thai rice millers and exporters, the Thaksin government also set explicit fund raising goals for each sector of the economy and appointed one or two "champions" in each industry which, in return to outsized payments, would enjoy unparalleled access to government largess. Under previous Thai governments, it was easier for virtually any firm that was willing to "pay the price" to enjoy the benefits of preferential government decisions.

50 “Thailand Grain and Feed New Rice Intervention Program Revised,” USDA report dated October 22, 2008. While providing a useful recap of the paddy pledging volume and the carryover stocks, the report incorrectly uses a milling rate of 55\% for 2003/04 through 2005/06 before correctly using $66 \%$ for the subsequent two years.
} 
causes panics, whether it is done by governments, traders, or households. ${ }^{51}$ At some point, though, the higher prices choke off demand from those that cannot afford them.

With world prices accelerating as the spring developed and the media brandishing numerous stories about the "Asian rice crisis," the price increases took on a life of their own as many buyers - both in exporting and importing countries - sought to hold extra stocks. Malaysia, for example, announced plans to increase Bernas' stock levels six-fold from two weeks (92,000 tons) to three months (550,000 tons). (It sent a team to Bangkok in May to secure 500,000 tons, but managed to buy only 200,000 tons. Apparently due to domestic political disagreements, the goal of three months of stocks was subsequently scrapped.) Nigeria, too, announced plans to increase imports by "an extra" 500,000 tons. This, too, failed to materialize after world prices reversed direction.

\section{Perception vs Reality}

India's Ban Was Not Absolute. In a number of key instances, there was a significant difference between perception and reality which materially impacted the amount of rice moving into the world market. In the case of India, for example, restrictions on rice exports did not significantly reduce non-Basmati exports until early 2008 and even then did not fully choke off sailings. During the six-month period between October 2007 and March 2008 when MEPs were in place, official statistics indicate over 2.5 million tons of non-Basmati was exported from India. While some of these shipments may reflect the execution of contracts signed before the imposition of stratospheric MEPs, it is likely that a significant tonnage reflected exporter evasion of the restriction by signing fake contracts and opening LCs at the officially stipulated price which were either later amended to reflect much lower world price levels or offsetting payments were made by the exporters to the buyers. Even after non-Basmati exports were banned on April 1, shipments of non-Basmati continued - above and beyond those exceptions allowed for the Gto-G sale to Bangladesh and that carved out for Bhutan, Sri Lanka, and others. During April through December, India exported an estimated 875,000 tons of nonBasmati, bringing calendar year 2008 movement to about 2.0 million tons or 3.25 million tons below year-earlier shipments. ${ }^{52}$

\footnotetext{
${ }^{51}$ The role of price speculation during the 2008 rice crisis is examined in "Did Speculation Affect World Rice Prices” by Peter Timmer, a paper presented to FAO’s workshop "Rice Policies in Asia” held in Chiang Mai, Thailand February 9-12, 2009.

${ }^{52}$ According to an official Indian Press Information Bureau press release, exports during this period were 717,000 tons (Source: http://pib.nic.in/others/prices/Brief_09.pdf) but the official trade books indicate a heavier movement of 839,000 tons of non-Basmati exported during April-October. Possibly reflecting contracts signed before the restrictions were put in place, India exported over 1 million tons of non-Basmati
} 
Cambodia's Exit Short-Lived; Brazilian “Ban” Mis-Interpreted. Cambodia's decision in late March to ban exports was given great play in the popular press assuming an importance totally detached from reality. Not only was the ban temporary - for two months - it was soon largely lifted. About two-thirds of the exports are made via Vietnam and the ban on shipments by the three eastern-most provinces was lifted within two weeks of the original announcement. Further, Cambodia is a very minor exporter (USDA estimates its annual exports average about 350,000 tons) and movement out of the country probably had largely occurred before the ban was announced - most of Cambodia's shipments occur around the beginning of the calendar year immediately after its main crop is harvested. Finally, the Cambodian-Vietnamese border is very porous and enforcement of the edict by Phnom Penh, even during this brief period, likely was hit and miss.

Similarly, at the peak of the crisis in late April it was reported that Brazil - also a minor exporter (USDA reports its exports over the preceding three years as averaging just over 250,000 tons) had banned all rice exports. Within a few days, it was clarified that this only involved government-held stocks - but most buyers likely did not hear of this distinction.

China Failed To Show Leadership. During the world rice crisis, it was widely reported that China, normally an annual exporter of approximately 1 million tons, had banned exports, but the picture was somewhat more complex. While Beijing in late 2007 had switched from subsidizing rice exports by 13\% to taxing the shipments by $5 \%$, it continued to execute contracts - albeit at a reduced level. Despite public and private appeals that China use its growing rice surpluses to partially fill the gap created by the exit of India and Vietnam from the market, China delayed issuing export quotas and shipped out only 56,000 tons at the peak of the market during April-June 2008, down from 170,000 tons during the same

during October-November 2007, including almost 365,000 tons to Africa. Strangely, another 893,000 tons of non-Basmati was recorded as exported during the next two months (including 165,000 tons to Africa) even though the MEPs were \$100-150/ton above Pakistani levels - suggesting that exporters were evading the MEP by the use of double invoicing. Non-Basmati exports - excluding those to Bangladesh, Sri Lanka, Nepal, and Bhutan - dwindled to 288,000 tons in February-March and then largely disappeared during April-October when over-invoicing to avoid the MEP was no longer an option.

Calendar year exports of both Basmati and non-Basmati are estimated at 3.35 million tons (compared to 6.26 million tons during 2007). 
period one year earlier. ${ }^{53}$ Chinese rice exports during the nine months ending in December totaled only 362,000 tons, off $37 \%$ from the same period one year earlier.

\section{Flames Brought Under Control}

In early May 2008 it appeared that the already catastrophic situation was getting worse. On May 3, Cyclone Nargis struck Burma's Irrawady Delta. At the time, preliminary estimates of the losses were as high as 2 million tons of paddy either lying in storage or unharvested in the fields and resulting in the government reportedly declaring force majeure on an estimated 100-150,000 tons of contracts. ${ }^{54}$ Just 9 days later, the world's $19^{\text {th }}$ most deadly earthquake hit China's Sichuan province, leaving 87,000 either confirmed dead or missing. In the intervening period, however, NFA's fifth tender had been aborted and the Philippines announced that it had withdrawn from the market as a buyer until the fall. Within two days, the Philippines secretly approached Japan for 200,000 tons of its imported rice, but Manila initially felt that Tokyo might not be forthcoming because of expected objections from the U.S. government.

On May 9, a cloud formed over the fire with the Center for Global Development (CGD) publishing a paper "Unwanted Rice in Japan Can Solve the Rice Crisis - If Washington and Tokyo Act" which argued that world prices could be cut to \$500$600 /$ ton by the end of June if existing stocks in Thailand, China, and Japan were to be exported. (Tokyo was holding over 1.5 million tons of imported rice and the paper pointed out that Beijing had inventories which were equivalent to four months of consumption so it could easily double its 2007 export level of 1.4 million tons. ${ }^{55}$ ) That same day, the Philippines publicly disclosed that it was negotiating with Japan for 60,000 tons of its domestic rice.

The proposal gathered momentum in Washington with questions raised in back-toback congressional hearings on May 12 in both the U.S. Senate and House of Representatives. The next day, the U.S. publicly indicated that it would not oppose Japan's re-export of rice; privately Washington also told Tokyo that it would not

\footnotetext{
${ }^{53}$ China's annual export quotas for rice are typically only decided by the National Development \& Reform Commission about one month after the end of the lunar New Year celebrations. As of late April 2008, however, a senior COFCo official was quoted as saying export quotas for 2008/09 still had not been issued. "China Continues to export rice this year,” China Knowledge, April 24, 2008.

${ }^{54}$ Loss estimates were subsequently sharply revised as the local populace salvaged rice which others would have refused to eat.

${ }^{55}$ http://cgdev.org/content/publications/detail/16028/
} 
press Japan to fulfill the balance of its 2007 buying commitments and those agreed upon for 2008 until after the crisis abated. Suddenly the world market began to realize that Japan's stocks of imported rice might come into play. While market fundamentals had not changed significantly, market sentiment clearly was beginning to shift.

Supply Conditions Change. In June, the market fundamentals began to improve. Cambodia, which had already lifted the remnants of its export ban, was claiming a record harvest and export availabilities in excess of 1 million tons. This was followed three weeks later with Vietnam on June 18 lifting its export ban on new sales. Equally

\begin{tabular}{|lcrr|}
\hline \multicolumn{4}{|c|}{ Table 3. VIETNAM: MRD } \\
Production (MMT) \\
Crop & '05/06 & '06/07 & '07/08 \\
$10^{\text {th }}$ & 1.43 & 1.37 & 1.14 \\
Spring & 9.00 & 9.10 & 9.60 \\
Autumn & 7.81 & 8.28 & 9.40 \\
Total & 18.23 & 18.74 & 20.14 \\
& & & \\
Source: USDA & & \\
\hline
\end{tabular}
important, Asian growers had reacted to the very high prices by significantly increasing their rice plantings. In the MRD, production of the combined winter-spring and summer-autumn crops jumped by almost 1.4 million tons, while in Thailand the dry season harvest is officially estimated to have increased by 2 million tons to an unprecedented 8 million tons. In Pakistan, farmers switched from sugarcane and cotton into rice with the result that the harvest is officially estimated to have increased by the equivalent of 1.0 million tons of milled rice to 6.5 million tons. In addition, the southwest monsoon arrived on time to the Indian subcontinent and was progressing favorably, increasingly pointing to a record harvest.

And Demand Recedes. In addition, import demand weakened significantly. Not only had the Philippines - the world's largest buyer completed its purchases, but expected demand from Indonesia failed to materialize. Also, fresh demand for shipment to Africa dried up as very large stocks had accumulated because of heavy shipments during the November 2007-March 2008 period and world prices had reached unaffordable levels. The combined sailings to Africa out of Thailand, Vietnam, and India during this five-month period totaled over 950,000 tons over that averaged during the same months during 2002-06.

In addition, declining rice prices coincided with collapsing freight prices. During the first week in June, the Baltic Dry Index (BDI) was recorded at 11612, but seven months later in the beginning of December it was only 666

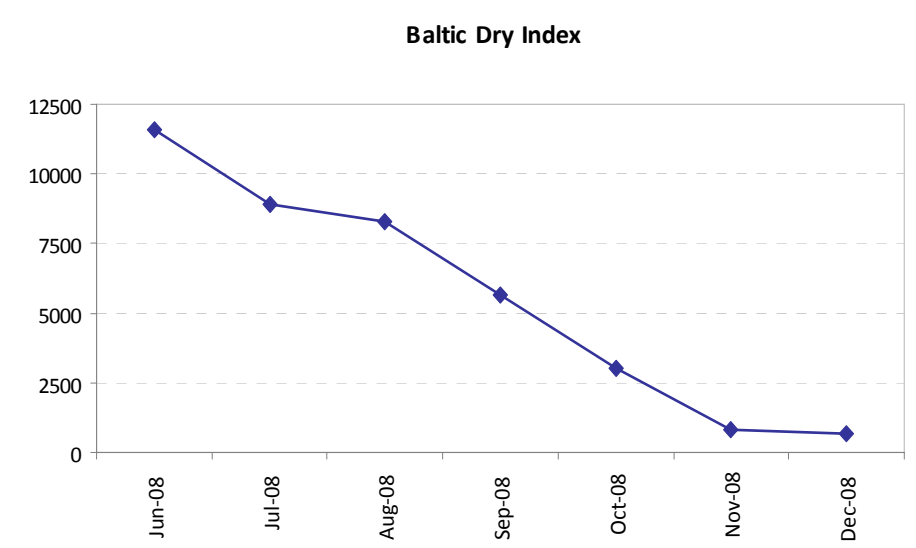


- a drop of $94 \%$. The decline in both rice and freight prices was so fast that international rice traders and their buyers found themselves saddled with expensive inventory at the destination. (The graph above tracks the BDI readings during the first week of each month.) Further, with the global credit crisis, the international banks became more vigilant lenders, especially for the smaller traders - at the origins, at the destinations, and in between.

Japanese Firefighters Fail To Respond To Alarms. While policymakers in the U.S. quickly responded to political and public pressure ignited by the CGD paper, giving Japan the green light to release its excess imported rice stocks, Tokyo's response was disappointing. At high level international meetings held in Rome in early June, Japan's P.M. Fukuda committed "to release in the near future over 300,000 tons of imported rice" to the world market. The public commitment, while more cautious than that hoped for by the U.S. government and the CGD authors, was welcomed. Once the public spotlight faded and the political leadership changed in Tokyo, even this pledge by Japan failed to be honored. Unofficial trade data shows that Japan's food aid shipments of rice declined in 2008 to less than 117,000 tons - more than 5,000 tons below that shipped one year earlier. While releasing its stocks would have relieved its exchequer significant costs for storing unwanted inventory, Japan's rice aid exports in 2008 were 91,000 tons below that averaged in the preceding five year period and were the lowest level shipped since $1997 .{ }^{56}$

\section{Forensic Findings \& A Preliminary Prognosis}

From the above, it is clear that last year's "fire" (the world rice crisis of 2008) was not a case of arson. It was the result of political considerations by Indian government leaders seeking re-election, which were compounded by profit-driven choices in Vietnam, and needlessly aggressive buying by the Philippines. Without this trifecta of policy decisions, world prices would not have reached the heights that were experienced. ${ }^{57}$ Natural causes, such as weather, the strong dollar, high oil prices, etc. played only a supporting role. The cold spell in northern Vietnam, for example, only ended up delaying the north's harvest, not severely impacting the output. (Storm losses in the Irrawady Delta and quake damage in China's

\footnotetext{
${ }^{56}$ Japan's failure to play a leadership role in "solving” the world food crisis by releasing its imported stocks as food aid to the Philippines and others is baffling as it was at the same time trumpeting plans to increase overseas development assistance to Africa. Perhaps bureaucrats in MAFF dug in their heels to "outside pressure." At the same time, however, the press reports that Japan was increasing its subsidized rice sales to its domestic feed industry by 50\%. "Japan May Raise Feed Wheat Imports as Substitute for U.S. Corn," Bloomberg, April 25, 2008.

${ }^{57}$ By the same token, the Thai government could have dampened the market by earlier disposing of its carryover stocks of 2.0 million tons.
} 
Sichuan province occurred only at the peak of the market, long after the fire was raging.) A strong dollar and high energy prices contributed to the updraft in world rice prices, but global rice values were already declining one month before oil prices peaked in July and two months in advance of the August high for urea.

While the governments in India, Vietnam, and the Philippines did not to set the world market on fire, that was the unintended result of their actions which threatened both innocent bystanders (low-income rice importers as far away as Africa and Latin America) and, ultimately, poor rice consumers at home.

Down, But Not Out. Has the world rice trading edifice been materially weakened by last year's events? Is "food fundamentalism" going to materially shrink the size of the world market and thereby increase volatility? In Asia, where the various food authorities were never dismantled, there is renewed wariness in depending on the world market and measures are being taken to increase self sufficiency. In the Middle East, where state trading enterprises are also very active, the governments, by and large, do not have the option of locally growing their rice needs. Some Middle Eastern governments and/or private investors, however, have announced ambitious plans to finance production of their food needs in third countries. In Africa and Latin America, where the various governmental food authorities were largely dismantled in the 1980s, the state generally does not have the mechanisms to effectively turn away from the world rice market.

In the Philippines, NFA's difficulty in securing its rice import needs has prompted a new-found commitment to the local rice sector. Not only has the government announced massive spending plans to reach rice self-sufficiency by 2013, but NFA is finally buying relatively large quantities of rice locally. Malaysia, too, has announced massive expenditures to increase rice production. In a bid to increase its rice self-sufficiency by 2010 to 86\%, Kuala Lumpur in April 2008 announced plans to invest almost $\$ 1.3$ billion in Sarawak to increase food production.

In Pakistan, the government, in fits and starts, has re-entered the market to provide price supports for rice farmers with the result that the country's export effort got off to a delayed and star-struck start. As a result, the narrow 3-4 month window that Pakistani exporters typically enjoy before they face intensified competition from Vietnam has been lost. In addition to delaying planting of the wheat crop, it also resulted in additional volumes of paddy remaining in the fields that were damaged by unseasonable December rains. PASSCO (Pakistan Agriculture Storage and Services Corporation) was directed to buy .5 MMT each of Basmati and non-Basmati at above-market prices. (The latter equated to \$325 FOB for white rice $25 \%$.) Originally this paddy was to be purchased directly from farmers, but the effort started slowly because PASSCO did not have the buying stations or storage facilities to perform the task and the specifications were unrealistic 
including a moisture content of $12 \%$. This eventually prompted it to utilize rice mills as intermediaries, but by this time many of the small and medium-sized farmers had already sold their harvest. (Controversially, actual buying has been far short of the targets.) In addition, the Trading Corporation of Pakistan (TCP) has been directed to export 1.5 million tons, reviving fears in the private trade about the corruption that thrived when the Rice Export Corporation of Pakistan was active. Indeed, TCP's first purchase in December 2008 is under investigation as it was concluded at approximately $\$ 137 /$ ton above prevailing local prices. ${ }^{58}$

Most of the rice consuming states in the Middle East do not have sufficient unutilized arable land to increase rice production, but many are exploring leasing/buying options in Africa and Asia. According to press reports, for example, the Saudi Binladen group expressed interest in spending over \$1.5 billion growing rice in Indonesia. Given the collapse in rice and oil prices during the second half of 2008, it remains to be seen the extent to which these projects will actually materialize. Not only are world rice prices no longer as attractive as they were when these investment ideas were conceived, there remain knotty issues of gaining permission to export the production from these projects in countries that are not rice self-sufficient. In early March 2009, for example, the Indonesian press reported that the Binladen project had been suspended. ${ }^{59}$

The 2008 rice crisis has prompted another raft of African proposals to sharply curtail rice import needs by stepped-up domestic production. Most African governments, however, long ago dismantled their agencies that were responsible for handling rice imports and provided price supports for local rice farmers. Further, local infrastructure is so poor that sharp increases in production may result in depressed prices in those locales.

Silver Linings. Last year's very high world prices have prompted stepped-up funding levels for plant research, extension, and irrigation infrastructure. In addition, it appears to have prompted a re-thinking of government attitudes vis-àvis GMOs - not only in China and, possibly, in India, but also in Africa. ${ }^{60}$

\footnotetext{
58 “Lowest TCP price bidder threatened,” The News, January 16, 2009.

59 “Binladin Freezes Plans To Invest in Local Rice” by Mita Valina Liem, Jakarta Globe, March 3, 2009. Available at http://www.thejakartaglobe.com/business/article/11843.html

60 "Gene altered crops gain favor, World's demand for food trumps doubters in many nations" Arkansas Democrat-Gazette, December 8, 2008.
} 


\section{Chronology of 2007-08 Rice Crisis}

2007

$\underline{\text { July }}$

21 Vietnam announces export sales ban for balance of 2007.

October

9 India bans exports of non-Basmati; food aid exports exempted. MSP announced of Rs 7,250/ton for Grade A paddy (including "bonus” of Rs 500) - up Rs 750 from one year earlier.

31 India replaces ban on non-Basmati with MEP of \$425 - \$100 above Pakistani 25\% price.

Thailand exports 1.1 million tons in October, the first of six consecutive months of shipments exceeding 1.0 million tons.

November

1 Speculation that world prices will hit $\$ 1,000$ at WRC conference in Nusa Dua, Indonesia

$7 \quad$ Food riots in Mauritania.

15 India raises MSP to Rs 7,750/ton of Grade A paddy, 19\% above one year earlier.

Cyclone Sidr slams Bangladesh, destroying 2.1 million tons of paddy and necessitating an additional 1 million tons of imports.

21 Food and fuel riots in Senegal.

December

1 India agrees to provide Bangladesh with 500,000 tons as food aid.

14 China ends VAT export rebate on rice of 13\% effective December 20

21 NFA tender 500,000 tons and buys 422,701 tons at an average price of $\$ 410$ CNF. Vietnam sells 410,701 tons.

27 India raises MEP on non-Basmati to $\$ 500$ - \$150 above Pakistani 25\%.

30 China announced 5\% export tax on rice effective January 1. 
31 Thailand's shipments exceed 9.5 million tons, while India records 6.3 million tons - including 5.25 million tons of non-Basmati. Vietnam's exports top 4.5 million tons.

\section{8}

January

14 Cold spell begins in northern Vietnam which over several weeks destroys 148,000 ha of transplanted rice and 10,000 ha of seedlings.

18 Vietnam's export target raised from 4.4 million tons to 4.5 million tons, including 700,000 tons January-March, 1.5 million tons each in second and third quarters, and 800,000 tons October-December. Exports are allowed to resume with MEP of $\$ 385$ for 5\% and \$360 for 25\% for January-February shipment and $\$ 400$ for $5 \%$ for March. Informally, VFA asks that no sales of $25 \%$ be made.

19 Apparently with large outstanding contracts at below current record market values and at government's urging, Egypt's exporters suspend exports.

20 Malaysia reports it is considering increasing Bernas' stock levels from two weeks to three months.

29 NFA tenders for 550,000 tons and buys 463,750 tons at an average price of \$475 CNF. Vietnam sells 300,000 tons.

Facing large losses on unshipped contracts concluded in late 2007, major exporters in Thailand stop offering price quotes.

\section{February}

$1 \quad$ NFA's stocks are equivalent to 8 days requirements, just over half of the targeted level of 15 days. (NFA's stocks are to be at least 30 days during the "lean" season.

Indonesia raises subsidized rice price by $60 \%$ while at same time increasing distribution quantity by $50 \%$.

4 India agrees to sell Bangladesh 500,000 tons on G-to-G basis at an average price of \$399 CNF with shipment to begin in February and to be completed within 75 days of contract signing. (Only 100,000 tons, however, was shipped at this price.) 
$5 \quad$ Vietnam informally bans new export sales by revoking MEP and not issuing any further MEPs during February.

8 China raises rice support prices by 6-8\%.

12 Egypt's export ban lifted.

In Thailand, pro-Thaksin party returns to power.

19 Food and fuel riots in Burkina Faso.

21 India signs first contract for 50,000 tons to be shipped to Bangladesh at \$399 CNF during February-March under December framework for 500,000 tons.

23 Riots break out in Cameroon over rising food and fuel prices and efforts by the president to extend his rule; 40 die as riots spread.

$\underline{\text { March }}$

5 India signs second contract for 50,000 tons to be shipped to Bangladesh at \$399 CNF under December framework for 500,000 tons.

6 Export quotas announced in Vietnam: January-March 700-800,000 tons, April-June 1.3-1.5 million tons, July-September 1.3-1.4 million tons, and October-December 700-800,000 tons. This effectively bans further sales in March given existing sales to NFA and others.

India raises non-Basmati MEP to \$650 - \$190 above Pakistani 25\%; MEP on Basmati established at $\$ 950$.

8 Egypt hikes export duty by $50 \%$ to just under $\$ 55 /$ ton.

China raises rice support prices by 5-7\%.

11 NFA tender 550,000 tons and buys 387,250 tons at an average price of $\$ 708 \mathrm{CNF}$ for $25 \%$ (328,500 tons), $\$ 738 \mathrm{CNF}$ for $15 \%$, and $\$ 745$ for $5 \%$ (15,625 tons each). Vietnam sells 231,250 tons. President Arroyo attends the filing of charges against rice hoarders and smugglers and rejects proposal to declare a state of emergency due to rising rice prices.

12 U.N. SecGeneral Ban warns world is "facing a perfect storm of new challenges." 
World wheat prices (HRW \#2 FOB Gulf) peak at \$532/ton.

14 Vietnam Food Association issues letter to members banning exports through April and promises guidance for May shipment at a later time.

17 First arrivals in Bangladesh from initial contract by India under promised 500,000 tons.

Vietnam bans further sales for March and April. Only sales for May allowed.

In Thailand, the vice-minister of commerce indicates that Bangkok may need to cap export prices.

19 The Agriculture Secretary in the Philippines urges restaurants and fast food outlets to cut rice servings by half to reduce waste so that imports can be reduced $37 \%$ to less than 1.2 million tons.

25 Vietnam extends export ban through June and reduces export target by .51.0 million tons to 3.5-4.0 million tons.

26 Vietnam decrees that no export contracts will be approved unless exporter is holding as stock $50 \%$ of the sale, prices must be in line w/ MEP, and shipment within 60 days; Export quotas revised: January-June 2.25 million tons (50\% of total exports in '06 and '07); 3.5 million tons thru September; MOU with the Philippines for 1.5 million tons announced.

Cambodia bans exports for two months.

27 India raises non-Basmati MEP to $\$ 1,000$ - $\$ 450$ above Pakistani 25\% -and scraps tax incentives for exports; MEP on Basmati rises to $\$ 1,100$.

Egypt bans exports until October 1.

China raises rice support prices by a further 3-4\%.

28 Commerce minister in Thailand told press that export prices would reach $\$ 1,000 /$ ton by June and that farmers should not be in a hurry to sell.

29 Export tax proposed in Vietnam.

Consumers empty store shelves in Hong Kong. 
31 Police in the Philippines begin to raid warehouses of suspected speculators.

Food riots in Ivory Coast.

Malaysia announces it will increase its rice stocks.

$\underline{\text { April }}$

1 India bans non-Basmati exports, Basmati MEP rises to $\$ 1,200$. Head of All India Rice Exporters' Association forecasts a 5.25 million ton drop in exports over the next twelve months.

In an effort to quell rising domestic prices, the minister of commerce indicates the government in Thailand will release up to 650,000 tons from its stockpiles into the domestic market at below-market prices.

In the Philippines, the government rejects a proposal to reduce the import tariff on rice from its current rate of $50 \%$.

In Hong Kong, the head of the Vermicelli and Noodle Manufacturing Industry Merchants predicted that prices would jump a further 30 percent by June.

2 In Thailand, an official at the exporters' association, citing "rice unrest" due to rising domestic prices, is quoted as warning that the government may restrict exports.

Police in the Philippines ask public to report speculators.

India agrees to exception to its export ban to supply Sri Lanka with 100,000 tons.

Following two days of rioting over high food prices, the Ivory Coast suspends import tariffs.

3 Bangladesh signs contracts to buy from India 400,000 tons at \$430 CNF for shipment within 60 days after LC opening under the 500,000 ton framework. Also, the head of the Bangladeshi military urges people to switch from rice to potatoes.

Support price in the Philippines raised to P $17 / \mathrm{kg}$ - 48\% above existing level and 62\% above year-earlier level, but only 25,000 tons procured by NFA during April-August. The agriculture secretary warns that milled rice 
prices potentially could quadruple. The government announces it will use army to deliver rice to the poor.

Head of Rice Exporters' Association of Pakistan urges government to not ban exports, but projects sailings will decline $15 \%$ in the year ending in June.

North Korea reported to suspend food rations in Pyongyang for six months.

$4 \quad$ With hoarding underway by rice mills, traders, and public, prime minister in Thailand assures there is enough rice for domestic consumption, but indicates commerce ministry plan to distribute subsidized rice is not necessary. Finance and commerce ministers repeat assurance that country will not restrict exports.

Following "summit" with government officials and farm experts on how to contain rice crisis, President Arroyo in the Philippines announces the government will spend over $\$ 1.0$ billion to increase rice production. The agriculture secretary tells press that 2007 imports could reach as high as 2.7 million tons.

Head of World Bank forecasts rising global food prices could push 100 million into deeper poverty. FAO's rice economist is quoted as forecasting that world prices will remain high for two to three years and will not stabilize for a couple of months.

5 In Thailand, minister of commerce holds "emergency" meeting with rice traders to brainstorm on country's rice policy on exports and assuring domestic consumption. Commerce minister urges government-held stocks to be kept as "safety stock" in case of bad weather during the next 6 months.

$6 \quad$ Cambodia lifts export ban for three provinces bordering Vietnam.

Bangladesh opens LC for 400,000 tons of Indian rice.

8 In the Philippines, the government indicates it will tender for 500,000 tons in May. NFA tenders for 100 TMT of U.S. \#2/4\%; purchased 72,600 tons for June-Sep shipment at average price of over $\$ 1,058$. 
10 Thailand's commerce minister announces that effective April 14 all retail rice prices will be reduced $10 \%$ for two months. Also, head of Internal Trade Department indicates that millers and exporters must report stock levels monthly and that army could be called in to guard rice warehouses. Also, exporters will be required to hold stock of 500 tons. Head of Thai rice exporters' association predicts 100\% B will soon reach \$1,000.

11 In a bid to limit exports and control local prices, Bulog is appointed the sole exporter in Indonesia of non-glutinous and non-fragrant rice and was prohibited from selling any rice unless its stocks were at least 3.0 million tons - more than double existing levels.

In Thailand, the commerce minister asks the military to guard the government-held stocks.

12 Food riots in Haiti result in prime minister being dismissed. Program announced to subsidize rice prices by $15 \%$.

Disclosed that government-held stocks in Thailand are missing 200,000 tons, leaving inventory at 2.1 million tons.

14 U.N. secretary general says global food crisis has reached "emergency proportions.”

17 NFA tenders for 500,000 tons and buys 364,000 tons at an average price of $\$ 1,075$ CNF for $25 \%$ (323,375 tons) and \$1,129 for 5\% (40,625 tons each).. Vietnam sells 80,000 tons (not including 20,875 tons sourced out of Pakistan via Long An Food).

Rumors that Pakistan will ban or otherwise restrict rice exports.

Bangladesh announces that military and police rations will switch to potatoes.

20 Malaysia announces $\$ 1.3$ billion plan to increase production of rice and other food products on Borneo.

Panic spreads to U.S. where press reports some Costco stores and other retailers are restricting sales of rice to counter hoarding efforts.

21 Indonesia raises support prices by 8-9\%. 
Rumors revive that Thailand could ban exports following statement by World Bank Vice President James Adams.

22 Japan scraps import tender in which it reportedly was offered $100 \%$ B at $\$ 1,300 /$ ton fearing that Tokyo would be blamed for pushing world prices higher.

Prime minister of Thailand denies country will restrict exports.

Bhutan reports that India has lifted its export ban to that country.

WFP executive director describes world food crisis as "silent tsunami."

23 Head of NFA indicates it is considering holding weekly import tenders.

Reports circulate that Brazil bans all exports, but later clarified that this applies only to government stocks.

AgMinister in Pakistan tells national assembly that government may ban exports if local prices are not well-behaved.

24 P.M. of Malaysia seeks guarantee that Thailand will not ban exports.

25 In Vietnam "rice fever" breaks out, prices have doubled in HCMC over the course of a couple of days.

India announces it will build 5 million ton "strategic reserve" of food grains, including 2 million tons of rice - beyond its stocking norms.

U.N. SecGeneral Ban calls for concerted and immediate action to solve global food crisis. Head of FAO tells press global food crisis could result in "civil wars."

28 Decree against speculators issued in Vietnam.

U.N. secretary general huddles with U.N. agency heads for two days to come up with plan for dealing with world food crisis.

29 India adds Basmati export tax of Rs 8,000/ton (approximately \$200/ton at then exchange rates) effective May 10.

Philippines requests Japan provide 60,000 tons of domestic rice. 
30 Thailand's prime minister revives proposed rice exporter cartel, OREC.

Pakistan announces MEPs, Super Basmati \$1,500, Basmati \$1,300, IRRI 9 \$1,000 and IRRI 6 \$750.

May

3 Cyclone Nargis slams Burma. According to preliminary initial estimates, 2 million tons of paddy was destroyed - both rice in fields awaiting harvest and stocks in hands of farmers and traders from both wet and dry season crops. After 32,725 tons sailed under existing commitments, Burma bans rice exports.

4 Head of VFA quoted as saying Vietnamese prices headed for $\$ 1,400$.

$5 \quad$ NFA tender for 675,000 tons fails as only one offer received and it without a sovereign guarantee; the Philippines talks of waiting until fall to buy. It indicates it will not, in any case, pay above $\$ 1,200 /$ ton.

6 Following objections from the Philippines and the ADB, Thailand scraps OREC proposal.

Idea of export tax floated in Vietnam.

7 Philippines informally requests that Japan provide 200,000 tons of imported rice.

9 NFA discloses that it is talking with Japan for 60,000 tons of domestic rice.

CGD paper "Unwanted Rice in Japan Can Solve the Rice Crisis - If Washington and Tokyo Act" published.

12 Malaysia fails in effort to buy 500,000 tons of Thai rice, but raises domestic support price by $15 \%$, announces domestic price controls for $5 \%$ and $10 \%$ rice effective June 1 , promises to spend up to $\$ 226$ million to subsidize imports of 500,000 tons, and intensifies its border control efforts.

Thailand sells 500 tons of stock (of an eventual 1,500 tons) into domestic market at $20 \%$ below market prices.

A massive earthquake strikes Sichuan, China killing as many as 87,000.

13 U.S. publicly indicates it would not oppose Japan's re-export of rice; privately it tells Tokyo that it will not press Japan to fulfill the balance of 
its 2007 buying commitments and those agreed upon for 2008 until after the crisis abates.

Malaysia buys from Thailand 100,000 tons each of 5\% at $\$ 950$ and 15\% at $\$ 940$.

Pakistan affirms it has additional 1 million tons available for export.

19 Philippines discloses Japan may also provide 200,000 tons imported rice.

21 Major exporters in Thailand resume offering price quotes.

23 Thailand's visiting prime minister reportedly tells President Arroyo that Bangkok is prepared to sell its stocks to the Philippines at friendship prices.

26 Cambodia lifts remaining export restrictions.

$\underline{\text { June }}$

2 At FAO summit on food crisis, Japan's P.M. Fukuda commits "to release in the near future over 300,000 tons of imported rice" to the world market. Japan also discloses Sri Lanka has requested up to 200,000 tons of food aid.

$4 \quad$ Faced with prospect of farmer protests and seeking to bolster his political support, Thailand's prime minister proposes to increase dry season paddy support price to Baht 14,000/ton (\$430) - 20\% above market - with a target of 2.5 million tons. Trade estimates this will result in FOB 100\% B prices of over $\$ 800$.

$9 \quad$ Egypt extends export ban until April 2009.

10 Prime minister takes commerce minister's proposal off cabinet agenda that would authorize Thailand to participate in NFA's request for G-to-G offers of 600,000 tons by June 13 .

12 Thailand's prime minister orders his staff to inspect government-held stocks.

13 Philippines receives offers for G-to-G purchase of 600,000 tons.

18 Vinafood G-to-G sale to NFA of 600,000 tons announced; first since 2003.

Vietnam's export ban lifted; MEP \$800 for 5\% established. 
$\underline{\mathrm{Jul}}$

3 World oil prices peak at over \$145/barrel. 